\title{
ОБГОВОРЮЄМО АКТУАЛЬНІ ПРОБЛЕМИ ПІДРУЧНИКОТВОРЕННЯ
}

\author{
28-29 травня 2020 р., м. Київ, Україна \\ https://doi.org/10.37472/2707-305X-2020-2-1-3-6
}

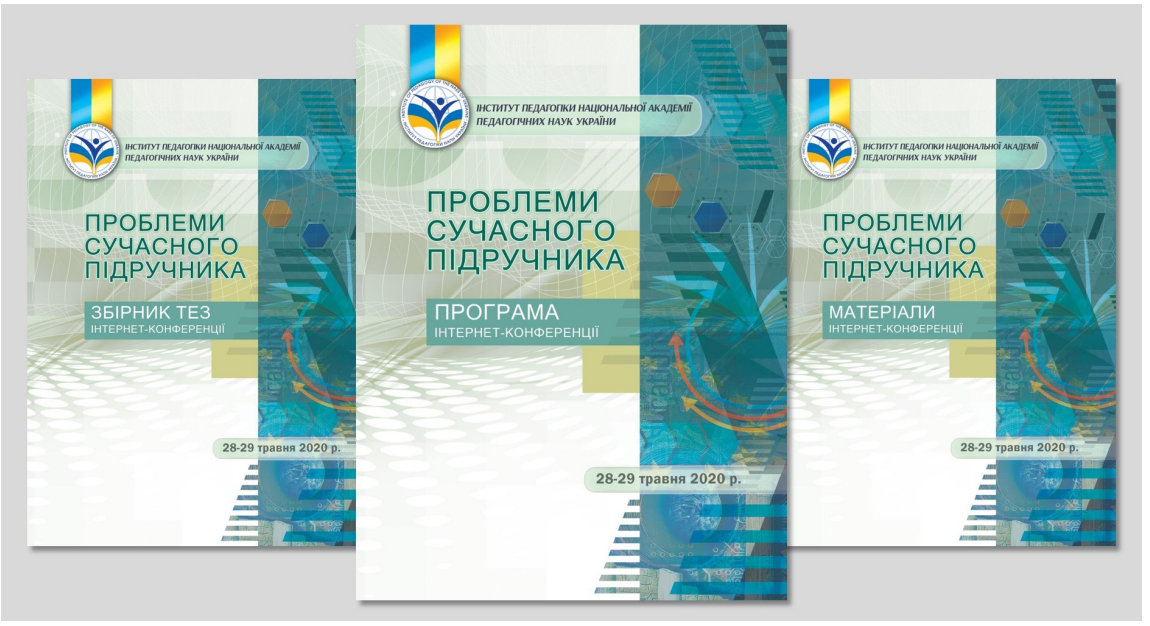

\section{3АCEKIHA \\ Тетяна Миколаївна \\ кандидат педагогічних наук, старший науковий співробітник, заступник директора з науково- експериментальної роботи Iнституту педагогіки Начіональної академії педагогічних наук України, м. Київ, Україна}

Анотація. У повідомленні висвітлено актуальні проблеми підручникотворення, що цього року розглядалися на Міжнародній науково-практичній інтернет-конференції «Проблеми сучасного підручника», організатором якої є Інститут педагогіки Національної академії педагогічних наук України. Серед найактуальніших питань - розроблення підручників за новими стандартами / курикулами; для вивчення інтегрованих курсів; для навчання дітей з особливими освітніми потребами; розроблення й оцінювання навчально-методичних комплексів, включаючи й електронні.

Ключові слова: підручники; зміст освіти; обмін досвідом.

Традиційно в травні до Дня науки Інститут педагогіки Національної академії педагогічних наук України разом із науковими установами й закладами освіти України і зарубіжжя проводить Міжнародну науково-практичну конференцію «Проблеми сучасного підручника». Цьогоріч співорганізаторами заходу стали: Державна наукова установа «Інститут модернізації змісту освіти», Науково-методична установа «Національний інститут освіти» Міністерства освіти Республіки Білорусь, Інститут педагогічних наук Республіки Молдова, Державна установа освіти «Академія післядипломної освіти» Республіки Білорусь. Зважаючи на карантинні заходи, обговорення актуальних питань підручникотворення уперше було здійснено в дистанційному режимі.

Директор Інституту педагогіки НАПН України О.М. Топузов відзначив, що в Інституті педагогіки НАПН України здійснено значну роботу з формування змісту освіти в Новій українській школі.
Науковцями Інституту створено й затверджено МOH України типові освітні програми для 1-2 та 3-4 класів (керівник - академік О.Я. Савченко). Підготовлено навчально-методичне забезпечення, зокрема 11 підручників для 1 класу, 12 підручників - для 2 класу. За результатами II етапу конкурсу, завершеного в березні 2020 р., рекомендовано до друку за кошти державного бюджету 7 підручників, розроблених вченими Інституту. Академік О.М.Топузов привернув увагу до новації у підручникотворенні - розробленні електронної підтримки підручників (QR-кодів, електронних додатків) тощо.

У своєму виступі академік-секретар Відділення загальної середньої освіти НАПН України O.І. Ляшенко наголосив, що оновлення змісту шкільної освіти відбувалось у різні часи, але було підпорядковано суті освітніх парадигм, що домінували на той час у професійному освітянському співтоваристві та суспільстві загалом. На думку вченого, нинішні стандарти освіти 
будуються за іншим принципом, ніж попередні. Зміст освіти окреслюється його компетентнісним потенціалом, який розкриває внесок кожної освітньої галузі у формування відповідних ключових компетентностей. Кожна з них характеризується певними результатами навчання, яких повинен досягти кожен учень/учениця по завершенні відповідного рівня середньої освіти або певного його циклу. На часі обговорення змісту базової освіти й реалізації його у підручниках для основної школи, зокрема для 5-6 класів. У цьому руслі відбувся обмін досвідом між учасниками 3 України, Молдови і Білорусі.

У 2019 р., як зазначив І. Акірі, доктор фізикоматематичних наук, конференціар Інституту педагогічних наук Республіки Молдова, розпочалося упровадження четвертого покоління шкільних курикулумів, що зумовлює оновлення підручників на засадах конструктивізму (структурності) та передбачає систематичне повторення вивченого матеріалу й основних понять як значущий аспект викладання-навчання. Водночас важливим аспектом $€$ формування особистості в освітньому процесі.

У доповіді Г.М. Юстінської, начальника управління дистанційних освітніх послуг Науковометодичної установи «Національний інститут освіти» Міністерства освіти Республіки Білорусь, представлено структурно-змістовну цілісність навчально-методичних комплексів (НМК), включаючи електронні, і навчальних предметів, а також аналізується ефективність їх використання в сучасній школі. Надано рекомендації з вивчення якості змісту компонентів НМК нового покоління. Сформульовано дидактичні принципи і функції НМК як основні критерії оцінки якості навчального продукту. Визначено характеристики електронних освітніх ресурсів як інноваційних компонентів НМК.

Важливою новацією упровадження стандартів нового покоління, на яку звернула увагу у своєму виступі заступник директора з науково-експериментальної роботи Інституту педагогіки НАПН України Т.М. Засєкіна, є можливість формування змісту предметів/інтегрованих курсів шляхом упорядкування у логічній послідовності результатів навчання кількох інтегрованих освітніх галузей, однієї освітньої галузі або ї̈ окремих складників. Хоча інтеграція в освітньому процесі не нове явище, але до цього часу тривають дискусії щодо її необхідності й доцільності. На думку вченої, необхідно виявити переваги й недоліки інтеграції, запропонувати апробовані та кращі їі моделі. Досвідом розроблення підручників до інтегрованих предметів поділилися наукові працівники відділу навчання мов національних меншин і зарубіжної літератури Інституту педагогіки НАПН України доктор педагогічних наук, завідувач відділу Н.І. Богданець-Білоскаленко та кандидат філологічних наук, провідний науковий співробітник О.Л. Фідкевич.

Іншому виду інтеграції - інтеграції «особливих» учнів до загальноосвітніх закладів - присвячено доповідь О.С. Хруль, завідувачки лабораторії спеціальної освіти Науково-методичної установи «Національний інститут освіти» Міністерства освіти Республіки Білорусь. Дослідниця підкреслила, що сьогоднішня практика стикається з певними труднощами, коли учні з особливостями розвитку формально інтегруються в освітній процес, виконуючи загальні для усього класу навчальні дії у «рамках можливостей особливої дитини». У такому разі вчені пропонують кілька моделей організації освітнього процесу з використанням відповідного навчально-методичного забезпечення:

1) створення спеціальних «інтегрованих» навчальних посібників (різнорівневих, з матеріалом для навчання різних категорій дітей);

2) використання у навчанні дітей з особливостями психофізичного розвитку посібників для загальноосвітніх установ зі спеціальними методичними рекомендаціями для учителя щодо коригування методичного апарату, теоретичного і практичного матеріалу;

3) паралельне використання в освітньому процесі навчальних посібників.

Актуальною залишається проблема розроблення підручників на засадах компетентнісного підходу, особливо підручників з математики. Як зазначає О.М. Пирютко, доцент кафедри математики й методики викладання математики Білоруського державного педагогічного університету імені М. Танка, посібники з предмета «Математика» у методичній системі $€$ найважливішим компонентом, від якого залежить результат проведених реформ у шкільній математичній освіті. Підручники з математики - це не просто засоби трансляції знань, що включають набір завдань для відпрацювання навичок застосування теорії. Вони мають містити комплекси практичних вправ, практико орієнтованих завдань, необхідних для самостійного освоєння нових знань у мінливому світі. 
Отже наведений вище обмін досвідом засвідчує спільні актуальні проблеми навчальнометодичного забезпечення й унікальні шляхи їх розв'язання, що реалізують освітні установи різних країн.
СПИСОК ВИКОРИСТАНИХ ДЖЕРЕЛ

Інститут педагогіки НАПН України. (2020). Міжнародна науково-практична інтернет-конферениія «Проблеми сучасного підручника». http://undip.org.ua/ working/konferentsiyi/270520/

Інститут педагогіки НАПН України. (n.d.). Електронна бібліотека. http://undip.org.ua/news/library/

\section{WE DISCUSS CURRENT ISSUES OF A TEXTBOOK DEVELOPMENT \\ May 28-29, 2020, Kyiv, Ukraine}

Tetiana Zasiekina

PhD in Pedagogy, Senior Researcher, Deputy Director for Scientific and Experimental Work, Institute of Pedagogy of the National Academy of Educational Sciences of Ukraine, Kyiv, Ukraine

Abstract. The current problems of textbooks' creation, which were considered this year at the International scientific and practical online conference "Problems of a Modern Textbook", organized by the Institute of Pedagogy of the National Academy of Educational Sciences of Ukraine, are highlighted in the material. Among the most pressing issues are the development of textbooks on new standards / curricula; to study the integrated courses; for teaching children with special educational needs; development and evaluation of educational and methodological complexes, including the electronic ones.

Keywords: textbooks; content of education; experience exchange. 